In PuRsuit of KNOWLEDge 



\section{IN PURSUIT of}

KNOWLEDGE

Scholars, Status, and

Academic Culture

Deborah L. Rhode

STANFORD LAW AND POLITICS

An imprint of Stanford University Press

Stanford, California 2006 
Stanford University Press

Stanford, California

C2006 by the Board of Trustees of the Leland Stanford Junior University. All rights reserved.

No part of this book may be reproduced or transmitted in any form or by any means, electronic or mechanical, including photocopying and recording, or in any information storage or retrieval system without the prior written permission of Stanford University Press.

\section{Library of Congress Cataloging-in-Publication Data}

Rhode, Deborah L.

In pursuit of knowledge : scholars, status, and academic culture / Deborah L. Rhode. p. $\mathrm{cm}$.

Includes bibliographical references and index.

ISBN-13: 978-0-8047-5534-4 (cloth : alk. paper)

ISBN-10: 0-8047-5534-5 (cloth : alk. paper)

1. College teachers--Professional relationships--United States. 2. Education, Higher-Aims and objectives--United States. 3. Universities and colleges--Research--United States. I. Title.

LB1778.2.R48 2007

$378.1^{\prime} 2--\mathrm{dc} 22$

2006023422

Designed by James P. Brommer

Typeset by Bruce Lundquist in 10.5/15 Minion 
for

J. PAUL LOMIO

and

THE STAFF OF THE STANFORD LAW LIBRARY 
